\section{Omega 3 Fatty Acids Reduce the Triglyceride Levels in Rats with Apical Periodontitis}

Mariane Maffei Azuma1, João Eduardo Gomes-Filho', Carolina de Barros Morais Cardoso ${ }^{1}$, Camila Barbosa Pipa ${ }^{1}$, Luis Gustavo Narciso², Suely Regina Mogami Bomfim², Rogério de Castilho Jacinto ${ }^{1}$, Luciano Tavares Angelo Cintra ${ }^{1}$
'Endodontics, Araçatuba Dental School, UNESP - Universidade Estadual Paulista, São Paulo, SP, Brazil ${ }^{2}$ Clinic and Surgery and Animal Reproduction, Araçatuba School of Veterinary Medicine, UNESP - Universidade Estadual Paulista, São Paulo, SP, Brazil

Correspondence: Dr. Luciano Tavares Angelo Cintra, R. José Bonifácio, 1193, Vila Mendonca, 16015-050 Araçatuba, SP, Araçatuba, SP, Brazil. Tel: +55-183636-2867. Fax: +55-18-3636-3253. e-mail: lucianocintra@foa.unesp.br
The aim of this study was to evaluate the influence of the prophylactic and therapeutic supplementation with omega 3 polyunsaturated fatty acids ( $\omega-3$ PUFAs) on the lipid profile and periapical bone resorption in rats with apical periodontitis. Forty male rats were divided into groups: control rats $(C)$, rats treated with $\omega-3$ PUFAs $(C+0)$, rats with pulp exposure-induced apical periodontitis (AP), and rats with AP treated with $\omega-3$ PUFAs $(A P+0)$. The administration of $\omega-3$ PUFAs was carried out orally once a day for 15 days before pulp exposure and, subsequently, for an additional 30 days after pulp exposure. AP was induced by exposing pulpal tissues to the oral environment. The samples were collected after 30 days. Triglycerides and cholesterol levels were enzymatically measured using the Trinder method. The jaws were collected and submitted for histological analysis. Two-way analysis of variance and Kruskal-Wallis tests were used for statistical analysis, and the significance was set at $p<0.05$. The triglyceride levels of the AP group were significantly higher than those of the $\mathrm{C}, \mathrm{C}+0$ and $\mathrm{AP}+0$ groups $(p<0.05)$. However, the difference in the cholesterol levels among the groups was not significant ( $p>0.05)$. Rats with AP showed larger areas of bone resorption as well as higher inflammatory intensity compared with rats with AP supplemented with $\omega-3$ PUFAs. It may be concluded that the presence of multiple AP foci increased the triglyceride levels. In addition, omega 3 supplementation might reduce these levels in rats with $\mathrm{AP}$, as well as the bone resorption areas of periapical tissues.
Key Words: apical periodontitis, lipid profile, omega 3 fatty acids, triglyceride levels, cholesterol levels.

\section{Introduction}

Apical periodontitis (AP) is an infectious disease characterized by pathologic bone destruction, which is mediated by various inflammatory mediators secreted from immunocompetent cells that have infiltrated the periapical tissues in response to intracanal bacterial infections (1). The influence of AP in systemic health has been studied, e.g., alterations in inflammatory cells, cytokines and lipid profiles in the blood (2-4). In this context, it has been observed that the presence of 1 focus of AP might enhance the levels of triglycerides in diabetic rats with periodontal disease (2). On the other hand, the presence of 1 focus of AP did not alter the cholesterol and triglyceride levels in normoglycemic rats (2). A systematic review using many cross-sectional studies indicated that the overall prevalence of perirradicular pathology in various patient populations is very high (5). Moreover, AP has occurred with an average of more than 2 lesions per patient (6). Thus, it would be very intriguing to study the impact of multiple AP foci on systemic health, with regard to the triglyceride and cholesterol levels. Also, alternative therapies that may reduce the lipid plasma levels that AP induces should be investigated.

Supplementation with omega 3 polyunsaturated fatty acids ( $\omega-3$ PUFAs) - mainly docosahexaenoic acid (DHA) and eicosapentaenoic (EPA)-can attenuate chronic inflammatory diseases via various mechanisms (7). Thus, $\omega-3$ PUFAs have protected mice against infections, regulated serum triglycerides and cholesterol levels, inhibited the synthesis of lipid mediators and altered the cellular functions of inflammatory cells $(8,9)$. Moreover, previous studies have demonstrated that $\omega-3$ PUFAs serve as a substrate for enzymatic conversion to a novel series of lipid mediators called resolvins and protectins (10). The production of resolvins and protectins, which are mediators of the resolution of inflammation, is very important clinically because they are related to the induction of bone regeneration, modulating osteoclast and osteoblast cells functions (11). Because of all of these properties, the use of $\omega-3$ PUFAs has been shown to have therapeutic value along with anti-inflammatory and protective actions in rheumatoid arthritis, cystic fibrosis, ulcerative colitis, 
asthma, atherosclerosis, cancer, cardiovascular disease and periodontitis (11). A previous study demonstrated that $\omega-3$ PUFAs not only decreased bone resorption but also promoted bone generation in the context of $\mathrm{AP}$, decreasing osteoclasts and increasing osteoblast cells (12).

Therefore, the aim of this study was to evaluate the influence of the prophylactic and therapeutic supplementation with omega 3 polyunsaturated fatty acids ( $\omega-3$ PUFAs) on the lipid profile and periapical bone resorption in rats with apical periodontitis.

\section{Material and Methods}

The Institutional Ethics Committee (CEUA 2014-00550) of Universidade Estadual Paulista, São Paulo, Brazil, approved the experimental protocol, which was conducted in accordance with relevant guidelines. Forty male Wistar rats (Rattus norvegicus albinus), 6 weeks old, weighing 200-250g each, were used in this study. The rats were housed in a mini-isolator for rats (Alesco, São Paulo, SP, Brazil) in temperature-controlled rooms and were given ad libitum access to water and food.

The rats were randomly assigned to 4 groups with 10 rats each: control untreated rats (C), rats treated with Joinville, SC, Brazil) (40 mg/kg; 60\% EPA and 40\% DHA), and the rats of the $C$ and $A P$ groups received filtrate water 15 days before AP induction (prophylactic administration) and 30 days after AP induction (therapeutic administration). This means supplementation with omega- 3 fatty acid or water took place for 45 days total (13).

The rats were intramuscularly anesthetized with ketamine $(87 \mathrm{mg} / \mathrm{kg}$; Francotar; Virbac do Brazil Ind. e Com. Ltda., Roseira, SP, Brazil) and xylazine (13 mg/kg; Rompun; Bayer S. A., São Paulo, SP, Brazil). The pulps of the right maxillary and mandibular first and second molars were exposed using surgical round burs (Broca Ln Long Neck; Maillefer, Dentisply Ind e Com Ltda, Petrópolis, Brazil) (groups $\mathrm{AP}$ and $\mathrm{AP}+0$ ) for the development of $\mathrm{AP}(2)$ and were analyzed via histological analysis.

After 30 days of pulp exposure, the animals were killed with an overdose of the anesthetic solution. To determine the serum lipid profile, venous blood samples ( $50 \mu \mathrm{l})$ were collected via cardiac puncture after the rats had fasted overnight for 8-12 h. The blood samples were centrifuged immediately after collection at $1,800 \times \mathrm{g}$ for $15 \mathrm{~min}$ at $4^{\circ} \mathrm{C}$ to obtain the plasma. The plasma total cholesterol and triglyceride levels were measured enzymatically by using a commercial kit (Cholesterol Liquiform Labtest ${ }^{\circledR}$ 
the AP group when compared with the $\mathrm{C}, \mathrm{C}+\mathrm{O}$ and $\mathrm{AP}+0$ groups $(p<0.05)$. No statically significant differences were found in the triglyceride levels among the $\mathrm{AP}+\mathrm{O}, \mathrm{C}+\mathrm{O}$ and C groups ( $p>0.05)$.

Representative hematoxylin-eosin-stained sections are shown in Figure 1. The histologic findings showed that all periapical tissues of teeth with pulp exposure developed apical periodontitis (Figures $1 \mathrm{C}$ and 1D). In addition, no inflammation was noted in the periapical region of the $C$ and $\mathrm{C}+0$ groups (Figures $1 \mathrm{~A}$ and $1 \mathrm{~B}$ ). However, in the $\mathrm{AP}$ and $\mathrm{AP}+\mathrm{O}$ groups, the pulp showed signs of total necrosis 30 days after pulp exposure, and the AP was established and restricted exclusively to the periapical region (Figures $1 C, 1 D, 1 G$ and $1 \mathrm{H})$. Furthermore, the AP was composed primarily of neutrophils (polymorphonuclears) and mononuclear cells. The statistical analysis showed that the magnitude of the inflammatory reaction and bone loss was higher in the AP group compared with the $\mathrm{AP}+\mathrm{O}$, $C+0$ and $C$ groups $(p<0.05)$ (Table 2). The inflammatory infiltrate was larger in the $\mathrm{AP}+0$ group when compared with the $\mathrm{C}$ and $\mathrm{C}+0$ groups $(\mathrm{p}<0.05)$ (Table 2 and Fig. 1). The area of the periapical lesion of the mandibular first molar was larger in the AP group when compared with the $A P+0$ group $(p<0.05)$ (Table 2 and Fig. 1).

\section{Discussion}

AP was induced by creating pulpal exposure in rats' molars and then allowing subsequent bacterial infection

Table 1. Mean and standard deviation $\left(m^{2} n_{ \pm} \mathrm{SD}\right)$ values of the lipid profiles (in milligrams per deciliter) of the rats from the 3 groups

\begin{tabular}{lcc}
\hline \multirow{2}{*}{ Groups } & \multicolumn{2}{c}{ Lipid profiles $\left(\text { mean }_{ \pm} \mathrm{SD}\right)^{*}$} \\
\cline { 2 - 3 } & Cholesterol levels & Triglyceride levels \\
\hline C & $63.30 \pm 10.10 \mathrm{a}$ & $56.78 \pm 13.89 \mathrm{a}$ \\
$\mathrm{C}+0$ & $66 \pm 7,86 \mathrm{a}$ & $58,33 \pm 17,82 \mathrm{a}$ \\
$\mathrm{AP}$ & $58.20 \pm 06.86 \mathrm{a}$ & $73.38 \pm 19.60 \mathrm{~b}$ \\
$\mathrm{AP}+0$ & $58.63 \pm 03.96 \mathrm{a}$ & $55.00 \pm 08.54 \mathrm{a}$ \\
\hline
\end{tabular}

*Same letters in the columns indicate the absence of statistical differences among the groups ( $p>0.05)$ to set in from the oral environment (2-4). This exposure was conducted over a 30-day period because this amount of time is sufficient to observe the development of AP and complete pulpal necrosis $(3,4)$. AP induction was confirmed using histological analysis. Our results showed that $\omega-3$ PUFAs decreased inflammatory cell infiltration as well as the AP bone resorption areas, which is in agreement with a previous study (12).

Rats received $\omega-3$ PUFAs in both prophylactic and therapeutic administration, as both types of administration showed better outcomes in suppressing the bone resorption induced in periodontitis compared with rats that received therapeutic administration alone (13). In addition, a previous study elucidated that the concomitant prophylactic and therapeutic administration of $\omega-3$ PUFAs decreased the bone resorption of rats with AP (12). To further explain, the prophylactic administration of omega 3 fatty acids for 2 weeks provides maximum increases in EPA and DHA levels in cell membranes (14), promoting and maintaining the membrane stability and fluidity in response to an inflammatory challenge caused by the induction of periodontitis.

Hypercholesterolemia induces pathologic manifestations, such as decreased myocardial capillary density and increased endothelial damage (15). Patients who develop periodontal diseases have shown increased total cholesterol levels, low-density lipoproteins, and triglyceride levels (16). On the other hand, a previous study performed using a rat's model showed that 1 AP focus did not alter the cholesterol levels is rats (2), which is in accordance with our results, as the presence of $4 \mathrm{AP}$ foci did not alter the total cholesterol levels in rats. Further studies should be performed in order to investigate the role of AP and the supplementation with $\omega-3$ PUFAs on the cholesterol parameters separately, as low-density lipoprotein (LDL), high-density lipoprotein (HDL), and very low-density lipoprotein (VLDL).

Hypertriglyceridemia is associated with cardiovascular risk according to several epidemiological studies (17). In addition, each $1-\mathrm{mmol} / \mathrm{l}(88 \mathrm{mg} / \mathrm{dl})$ decrease in triglyceride levels has been associated with a decrease in the risk of coronary heart disease in 14\% of men and 37\% of

Table 2. Scores and median of intensity of inflammatory cells and AP area (mm2) according to the groups

\begin{tabular}{|c|c|c|c|c|c|}
\hline \multirow{2}{*}{ Intensity of inflammatory cells } & \multicolumn{4}{|c|}{ Groups } & \multirow{2}{*}{ Statistical analysis } \\
\hline & $\mathrm{C}$ & $\mathrm{C}+\mathrm{O}$ & $\mathrm{AP}$ & $\mathrm{AP}+0$ & \\
\hline 1: absent & $10 / 10$ & $10 / 10$ & $0 / 10$ & $0 / 10$ & \multirow{4}{*}{ Kruskal-Wallis $(\mathrm{p}<0.05$} \\
\hline 2: mild & $0 / 10$ & $0 / 10$ & $0 / 10$ & $4 / 10$ & \\
\hline 3: moderate & $0 / 10$ & $0 / 10$ & $4 / 10$ & $6 / 10$ & \\
\hline 4: severe & $0 / 10$ & $0 / 10$ & $6 / 10$ & $0 / 10$ & \\
\hline $\mathrm{AP}$ area $\left(\times 10^{4} \mu \mathrm{m}^{2} \pm \mathrm{SD}\right)$ & $13.1 \pm 1.39 \mathrm{a}$ & $12.53 \pm 1.07 \mathrm{a}$ & $84.82 \pm 30.7 \mathrm{~b}$ & $46.58 \pm 17.7 c$ & t- Student $(\mathrm{p}<0.05)$ \\
\hline
\end{tabular}

*Same letters in the columns indicate the absence of statistically significant differences among the groups ( $>0.05$ ). 
woman (18). Previous studies showed that the presence and severity of periodontal diseases alter the triglyceride levels in humans $(19,20)$, which is in accordance with this study, which observed an increase in the triglyceride serum levels of rats in the presence of 4 AP foci, showing that endodontic infections may influence systemic health. On the other hand, another study showed that only 1 AP focus did not alter the triglyceride levels of rats (2).
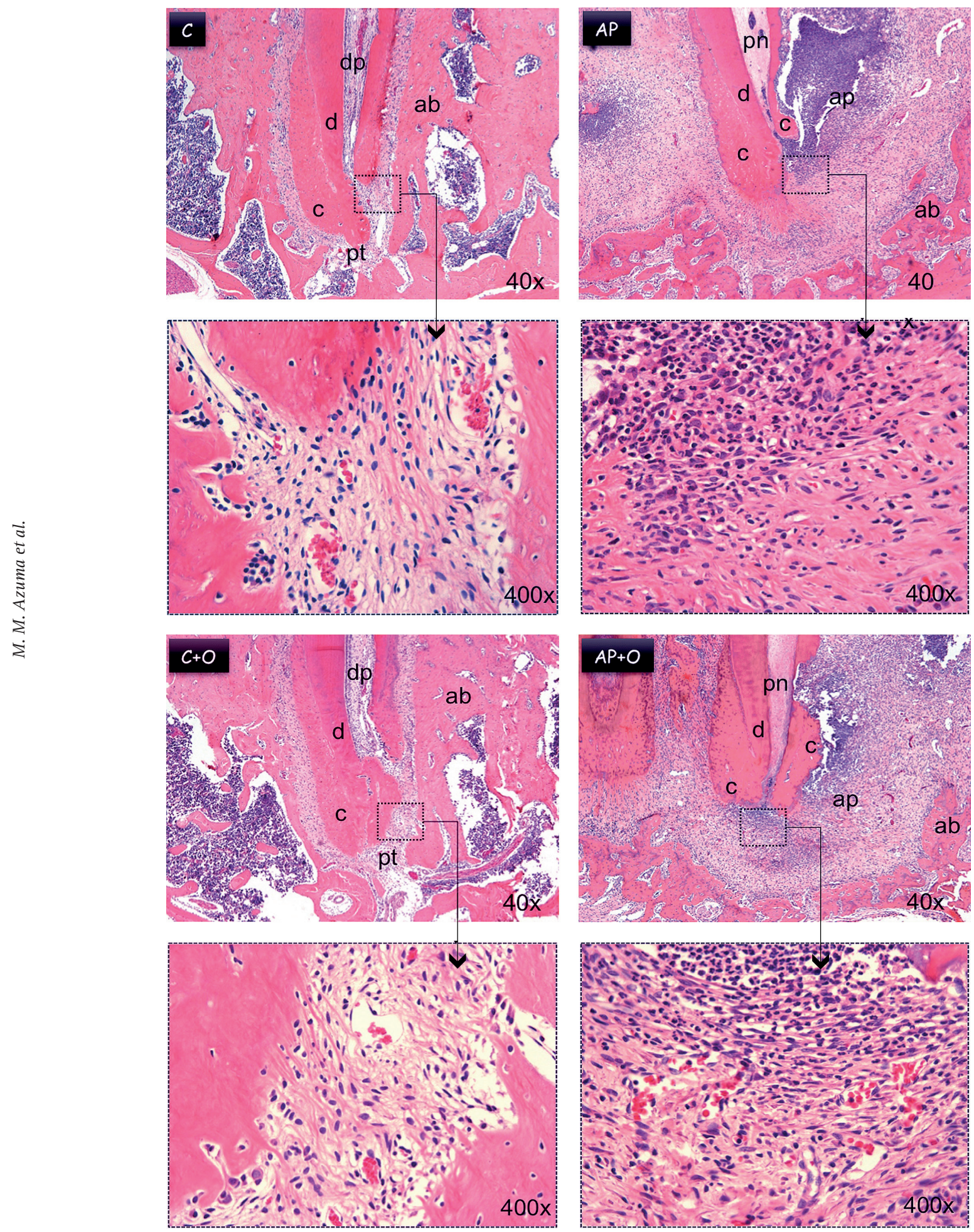

Figure 1. Representative photomicrography of healthy molars (groups $\mathrm{C}$ and $\mathrm{C}+\mathrm{O}$ ) and molars with $\mathrm{AP}$ after 30 days (groups $\mathrm{AP}$ and $\mathrm{AP}+0$ ). $\mathrm{C}$ and $\mathrm{C}+\mathrm{O}$ : Normal aspects of pulp tissue and periodontal insertion in the periapical region. AP and AP+O: Molars with apical periodontitis showing pulp necrosis and established periapical lesion with the presence of neutrophils (polymorphonuclears) and mononuclear cells. Hematoxylin-eosin staining, 40x and 400x original magnifications. Abbreviations: dp, dental pulp; d, dentin; c, cementum; pt, periapical tissues; ab, alveolar bone; pn, pulp necrosis; ap, apical periodontitis. 
Therefore, the systemic alteration may be proportional to the amount and severity of the infection sites. An increase on triglycerides levels as a consequence of AP may be related to the presence of bacteria and its lipopolysaccharides (LPS). Previous studies have demonstrated that LPS-induced hypertriglyceridemia is due to a delay in catabolism of circulating lipids, as well as to decrease in adipose tissue lipoprotein lipase activity $(21,22)$. Another hypothesis is that the proinflammatory cytokines released during AP development (23), may increase the mobilization of lipids from liver and adipose tissue (24), altering theirs levels systemically.

In this study, the dietary with $\omega-3$ PUFAs reduced the bone resorption area and inflammation of rats with endodontic infection, which is in agreement with a previous study (12). In addition the dietary with $\omega-3$ PUFAs fatty acids reduced the triglyceride levels in rats with endodontic infections. Since periapical periodontitis is associated with an increase in some proinflammatory cytokines in blood (23), a decrease in the AP inflammation may be associated with the reduction of serum triglycerides levels. Another hypothesis is the fact that the main mechanism of $\omega-3$ PUFAs is the direct inhibition of triglyceride synthesis and reduction of very-low-density lipoprotein assembly and secretion (25).

Therefore, the dietary with omega 3 fatty acids proved to be an alternative to reducing the triglyceride levels in individuals with 4 AP foci. The results of our study showed that the presence of multiple AP foci increases the triglyceride levels in rats. In addition, the diet with omega 3 fatty acids may reduce the triglyceride levels that have already been altered by AP as well as the bone resorption of periapical tissues.

\section{Resumo}

0 objetivo deste estudo foi avaliar a influência da suplementação profilática e terapêutica com os ácidos graxos ômega-3 no perfil lipídico e na reabsorção óssea, em ratos com periodontite apical. Quarenta ratos machos foram divididos em grupos: ratos controle (C), ratos tratados com ácidos graxos ômega-3 $(\mathrm{C}+0)$, ratos com periodontite apical induzida por meio de exposição pulpar (PA), ratos com PA tratados com ácidos graxos ômega-3 (PA+0). A administração do ômega-3 foi realizada oralmente, uma vez ao dia durante 15 antes da exposição pulpar e, subsequentemente, por mais 30 dias depois da exposição pulpar. A PA foi induzida por meio da exposição do tecido pulpar ao ambiente oral. Após 30 dias, os ratos foram mortos e os niveis de triglicérides e colesterol foram mensurados pelo método enzimático de Trinder. As mandibulas foram coletadas e submetidas à análise histológica. Análise de variância de dois fatores e teste de Kruskal-Wallis foram utilizados para análise estatistica, e o nivel de significância foi de $p<0,05$. Os níveis de triglicérides do grupo $\mathrm{PA}$ foram significativamente maiores que dos grupos $\mathrm{C}, \mathrm{C}+0$ e $\mathrm{PA}+0$ $(p<0,05)$. Entretanto, não houve diferença significativa nos niveis de colesterol entre os grupos $(p>0,05)$. Ratos com PA apresentaram maior área de reabsorção óssea bem como maior intensidade no infiltrado inflamatório comparados aos ratos com PA suplementados com ômega-3. Pode-se concluir que a presença de múltiplos focos de PA aumentou os níveis de triglicérides. Além disso, a suplementação com ômega-3 pode reduzir estes niveis em ratos com PA, bem como a área de reabsorção óssea dos tecidos periapicais.

\section{Acknowledgements}

We are grateful to Fapesp for providing the financial support (FAPESP 2013/26390-0 and 2015/03054-0).

\section{References}

1. Kawashima N, Okiji T, Kosaka T, Suda H. Kinetics of macrophages and lymphoid cells during the development of experimentally induced periapical lesions in rat molars: a quantitative immunohistochemical study. J Endod 1996;22:311-316.

2. Cintra LT, da Silva Facundo AC, Azuma MM, Sumida DH, Astolphi RD, Bomfim SR, et al. Pulpal and periodontal diseases increase triglyceride levels in diabetic rats. Clin Oral Investig 2013;17:1595-1599.

3. Cintra LT, da Silva Facundo AC, Prieto AK, Sumida DH, Narciso LG, Mogami Bomfim SR, et al.. Blood profile and histology in oral infections associated with diabetes. J Endod 2014;40:1139-1144.

4. Cintra LT, Samuel RO, Azuma MM, Ribeiro CP, Narciso LG, de Lima $\mathrm{VM}$, et al. Apical periodontitis and periodontal disease increase serum IL-17 levels in normoglycemic and diabetic rats. Clin Oral Investig 2014;18:2123-2128.

5. Park JG, Favazi S, White SN. Prevalence of periapical radiolucency and root canal treatment: a systematic review of cross-sectional studies. J Endod 2012;38:1170-1176.

6. Marotta PS, Fontes TV, Armada L, Lima KC, Rôças IN, Siqueira JF Jr. Type 2 diabetes mellitus and the prevalence of apical periodontitis and endodontic treatment in an adult Brazilian population. J Endod 2012;38:297-300.

7. De Caterina R, Basta G. n-3 Fatty acids and the inflammatory responsed biological background. Eur Heart J 2001;3:42-49.

8. Alam SQ, Bergens BM, Alam BS. Arachidonic acid, prostaglandin E2 and leukotriene $\mathrm{C} 4$ levels in gingival and submandibular salivary glands of rats fed diets containing n-3 fatty acids. Lipids 1991;26:895-900.

9. Fernandes G, Venkataraman J. Role of omega-3 fatty acids in health and disease. Nutr Res 1993;13:19-45.

10. Serhan CN, Chiang N, Van Dyke TE. Resolving inflammation: Dual antiinflammatory and pro-resolution lipid mediators. Nat Rev Immunol 2008;8:349-361.

11. Herrera BS, Ohira $T$, Gao L, Omori $K$, Yang $R$, Zhu $M$, et al. An endogenous regulator of inflammation, resolvin $\mathrm{E} 1$, modulates osteoclast differentiation and bone resorption. Br J Pharmacol 2008; 155:1214-1223.

12. Azuma MM, Gomes-Filho JE, Ervolino E, Pipa CB, Cardoso CBM, Andrada $A C$, et al. Omega 3 fatty acids reduce bone resorption while promoting bone generation in rat apical periodontitis. J Endod 2017;43:970-976.

13. Vardar $S$, Buduneli $E$, Türkoglu 0 , Berdeli AH, Baylas $H$, Baskesen $A$, et al. Therapeutic versus prophylactic plus therapeutic administration of omega3 fatty acid on endotoxin-inducedperiodontitis in rats. J Periodontol 2004;75:1640-1646.

14. Croft KD, Beilin $\amalg$, Loece FM, Vandongen R. Effects of diet enriched eicosapentaenoic or docosahexaenoic acid or prostanoid metabolism in the rat. Lipids 1987;22:647-650.

15. Stapleton PA, Goodwill AG, James ME, Brock RW, Frisbee JC. Hypercholesterolemia and microvascular dysfunction: interventional strategies. J Inflamm 2010;7:54.

16. Katz J, Flugelman MY, Goldberg A, Heft M. Association between periodontal pockets and elevated cholesterol and low density lipoprotein cholesterol levels. J Periodontol 2002;73:494-500.

17. Freiberg JJ, Tybjaerg-Hansen A, Jensen JS, Nordestgaard BG. Nonfasting triglycerides and risk of ischemic stroke in the general population. JAMA 2008;300:2142-2152.

18. Hokanson JE, Austin MA. Plasma triglyceride level is a risk factor for cardiovascular disease independent of high-density lipoprotein cholesterol level: a meta-analysis of population-based prospective studies. J Cardiovasc Risk 1996;3:213-219. 
19. Lee JB, Yi HY, Bae KH. The association between periodontitis and dyslipidemia based on the Fourth Korea National Health and Nutrition Examination Survey. J Clin Periodontol 2013;40:437-442.

20. Flores MF, Montenegro MM, Furtado MV, Polanczyk CA, Rösing CK, Haas AN. Periodontal status affects $\mathrm{C}$-reactive protein and lipids in patients with stable heart disease from a tertiary care cardiovascular clinic. J Periodontol 2014;85:545-553.

21. Kaufmann RL, Matson CF, Beisel WR. Hypertriglyceridemia produced by endotoxin: role of impaired triglyceride disposal mechanisms J Infect Dis, 1976.

22. Uchiumi D, Kobayashi M, Tachikawa $T$, Hasegawa K. Subcutaneous and continuous administration of lipopolysaccharide increases serum levels of triglyceride and monocyte chemoattractant protein-1 in rats.
J Periodontal Res 2004;39:120-128.

23. Cintra LT, Samuel RO, Azuma MM, de Queiróz AO, Ervolino E, Sumida DH, et al. Multiple Apical Periodontitis Influences Serum Levels of Cytokines and Nitric Oxide. J Endod 2016;42:747-751.

24. Iacopino AM, Cutler CW. Pathophysiological relationships between periodontitis and systemic disease: recent concepts involving serum lipids. J Periodontol 2000;71:1375-1384.

25. Jacobson TA. Role of $n-3$ fatty acids in the treatment of hypertriglyceridemia and cardiovascular disease. Am J Clin Nutr 2008;87:1981S-1990S.
Accepted October 1, 2017 Received November 20, 2017 